\title{
Eksistensi Tari Tradisional Megoak-Goakan sebagai Etnisitas Budaya di Kabupaten Buleleng
}

\author{
Ni Luh Sustiawati, I Nyoman Cerita, Ni Ketut Suryatini \\ Institut Seni Indonesia Denpasar \\ Jalan Nusa Indah, Sumerta, Denpasar, Kota Denpasar, Bali 80235 \\ Tlp. 081389050155, E-mail: sustiawatiniluh@gmail.com
}

\begin{abstract}
The traditional Magoak-goakan dance is a reflection of the local culture of Buleleng district which is full and strong with ethical, aesthetic, and logical values. As a representation of cultural ethnicity, this dance is an ancestral heritage of the people of North Bali and has become the treasure of a noble Balinese culture. This dance is inspired by the traditional game of Magoak-goakan which was initiated by the King of Buleleng Ki Barak Panji Sakti in 1660 AD in Panji village, Sukasada district. This study aims to describe the existence of the traditional Magoak-goakan dance. This research has a qualitative approach, the data collection techniques used are observation, interviews, and documentation. The results of the study indicate that the existence of the traditional Magoak-goa dance has an important role in the socio-cultural life of the Buleleng community so that it needs to be preserved and developed based on the entity and the quality and the principles possessed. Another important role as a source of cultural arts learning in schools, especially in the competence to appreciate and express traditional arts.
\end{abstract}

Keywords: existence, megoak-goakan dance, ethnicity, and culture.

\begin{abstract}
ABSTRAK
Tari tradisional Magoak-goakan merupakan refleksi budaya lokal kabupaten Buleleng yang sarat dan kuat dengan nilai-nilai etika, estetika, dan logika. Sebagai representasi etnisitas budaya, tarian ini merupakan warisan leluhur masyarakat Bali Utara dan telah menjadi khasanah budaya Bali yang adiluhung. Tari ini terinspirasi dari permainan tradisional Magoak-goakan yang dicetuskan oleh Raja Buleleng Ki Barak Panji Sakti pada tahun 1660 M di desa Panji, kecamatan Sukasada. Penelitian ini bertujuan mendeskripsikan keberadaan tari tradisional Magoak-goakan. Penelitian ini berpendekatan kualitatif, teknik pengumpulan datanya digunakan observasi, wawancara, dan dokumentasi. Hasil penelitian menunjukan bahwa eksistensi tari tradisional Magoak-goakan memiliki peranan penting dalam kehidupan sosiokultural masyarakat Buleleng sehingga perlu dilestarikan dan dikembangkan berdasarkan entitas dan kualitas serta kaedah-kaedah yang dimiliki. Peran penting lainnya sebagai sumber pembelajaran seni budaya di sekolah, khususnya pada kompetensi mengapresiasi dan mengekspresikan seni tradisi.
\end{abstract}

Kata kunci: eksistensi, tari megoak-goakan, suku, dan budaya

\section{PENDAHULUAN}

Kabupaten Buleleng secara historis merupakan daerah seni dengan menjungjung tinggi nilai-nilai adat dan tradisi yang kuat serta dilandasi keyakinan agama Hindu yang kokoh, sehingga membuat tari-tari tradisional bisa hidup dengan subur, yang salah satunya adalah tari Magoak-goakan. Tari Magoak-goakan sebagai salah satu tari tradisional khas kabupaten Buleleng telah 
mengalami perjalanan sejarah yang cukup lama dengan mendapatkan pengaruh secara integral dan kental dari budaya masyarakat pendukungnya. Kehadirannya di tengahtengah masyarakat telah menjadi bagian dari kehidupan yang berbudaya baik secara realitas dalam kehidupanan nyata (sekala) maupun nonrealitas (niskala). Diikat dengan norma-norma atau pakem-pakem yang ketat dan kuat, dengan kerakteristiknya yang unik dan menarik, mengandung nilai-nilai artistik dan filosofis yang tinggi, di mana telah diyakini memiliki fungsi dan makna penting di dalam kehidupan masyarakatnya yang bersifat magis religius, yaitu: makna moral, intelektual, dan spiritual.

Dalam aspek nilai, tari tradisional Magoak-goakan sebagai bagian dari seni pertunjukan yang tidak hanya berfungsi sebagai tontonan semata, namun lebih dari itu adalah memiliki fungsi sebagai tuntunan dan tatanan. Apabila dipandang sebagai media pembelajaran memiliki konstribusi besar dalam memberikan tuntunan dan pencerahan terhadap masyarakatnya. Materi-materi pendidikan di dalamnya, yaitu memperkokoh jiwa persatuan dan kesatuan dalam masyarakat; meningkatkan rasa solidaritas; keharmonisan dengan saling menghargai dan menghormati dalam balutan multikulturalisme; memperkuat kepribadian dan kebanggaan wilayahnya; menjunjung tinggi nilai-nilai dan martabat serta status sosial masyarakat; dan memperhalus budi dan sikap dari masyarakat. Sebagai sumber ilmu pengetahuan memiliki makna, yaitu dapat membentuk karakter dan jati diri; mempertebal rasa percaya diri; dan membuka wawasan pengalaman pada setiap orang yang dapat dijadikan pedoman dalam menjalani kehidupan sehari-hari. Apabila diposisikan sebagai media spiritual, tari ini merupakan sarana yang bersifat magis religius yang dalam aspek semiotika sebagai proses pendewasaan rohani dan jasmani kehidupan masyarakatnya melalui pemahaman, penghayatan fungsi, dan makna simbol-simbol yang dirangkai dengan indah dan menarik dan sakral. Hal ini diyakini oleh umat Hindu di Bali khususnya masyarakat Buleleng dapat dijadikan media untuk mendekatkan diri, mempertebal rasa srada dan bakti terhadap Ida Sang Hyang Widhi Wasa/Tuhan Yang Maha Esa untuk mencapai ajaran-Nya yaitu kebenaran (dharma).

Dalam sejarah umat manusia dikenal sejumlah lembaga kebenaran sebagai media untuk mencari dan menemukan kebenarannya sendiri, yaitu agama, ilmu, filsafat, dan seni (Sumardjo, 2000, hlm. 4). Keempat lembaga kebenaran tersebut, agama dan seni memiliki fungsi serta makna yang dekat. Lebih jauh Sumardjo (2000, hlm. 4-5) mengatakan bahwa agama melalui keyakinan dapat menjangkau kebenaran mendasar, universal, menyeluruh, dan mutlak serta abadi. Seni pun menjangkau hal-hal tersebut dan dalam seni, alat untuk mencapai hal itu adalah perasaan dan intuisi. Beranalogi dari perdapat tersebut, dalam sosiokultural masyarakat Buleleng tari Magoak-goakan telah menjadi milik masyarakat bahkan telah menjadi darah dagingnya di mana ibarat kehidupan manusia, yaitu wujud dari tari adalah fisiknya sendiri dan isi atau bobotnya merupakan budaya, dan agama Hindu sebagai jiwanya. Keterpautan seni tari dengan agama Hindu di Bali khususnya dalam 
masyarakat Buleleng telah menjadi khasanah budaya yang tetap eksis hingga sekarang. Berkaca dari hal tersebut tari tradisional Magoak-goakan sebagai salah satu kesenian etnik Bali Utara (Kabupaten Buleleng) dengan kemuliaan fungsi dan maknanya dipandang perlu dilestarikan dan dikembangkan sesuai dengan etika, logika, dan estetika yang tersirat dan tersurat di dalamnya.

Belakangan ini derasnya pengaruh globalisasi yang ditandai dengan pesatnya perkembangan teknologi, telekomunikasi, informasi, dan sains sehingga sangat sulit membendung perubahan-perubahan budaya yang begitu cepat. Globalisasi yang menyatukan Bali dengan negara-negara kapitalisme global-Bali sebagai bagian dari kampung global, mengakibatkan agama pasar dengan cepat masuk ke dalam sistem sosio-budaya Bali (Atmaja, 2010, hlm. 74). Menghadapi fenomena seperti itu, muncul kekuatiran di kalangan masyarakat baik formal maupun nonformal tentang pelestarian dan perkembangannya bahwa tari tradisional Magoak-goakan akan terjadi pergeseran nilai yang dianggapnya telah mapan. Secara teoretis, pandangan seperti ini sangat logis, karena unsur-unsur budaya, termasuk keseniannya yang dipandang berfungsi penting bagi kehidupan masyarakat akan tetap survive di tengah-tengah masyarakat yang sezaman. Dengan pengertian lain bahwa, jika masyarakat dan kebudayaannya mengalami perubahan maka tidak tertutup kemungkinannya bahwa nilai artistik dan filosofi seni tari ikut berubah mengikuti zamannya. Oleh karena itu, seni tari tersebut tetap bertahan dan bahkan berkembang sesuai dengan kondisi sosio-kultural masyarakat yang bersangkutan (Cerita, 2020, hlm. 32).

Pada era reformasi seperti sekarang ini ada perubahan di segala lini dengan melibatkan seluruh lapisan masyarakat baik bidang pendidikan, ekonomi, politik, pemerintahan, dan sosial budaya. Menurut Lijan Poltak Sinambela (2014, hlm. 25) bahwa reformasi mengandung pengertian penataan kembali bangunan masyarakat, termasuk cita-cita, lembaga-lembaga, dan saluran yang ditempuh dalam mencapai cita-cita. Reformasi di segala bidang yang di dalamnya termasuk bidang seni dan budaya merupakan paradigma baru terhadap perubahan dan pembaharuan bagi kehidupan masyarakat. Hal ini tidak bisa dipungkhiri bahwa, tari-tari tradisional yang memiliki nilai luhur yang merupakan warisan leluhur dan telah menjadi khasanah budaya Bali yang adiluhung, termasuk salah satunya adalah tari Magoak-goakan diasumsikan akan mengalami marginalisasi, tergerus oleh derasnya arus globalisasi.

Berdasarkan pemikiran termasuk dugaan-dugaan tentang fenomena sosial masyarakat di era global itu dijadikan alasan bahwa selayaknya tari tradisional Magoakgoakan diberikan perhatian khusus dan serius dalam menjaga eksistensinya. Oleh karena itu, tidaklah berlebihan tarian ini dilestarikan dan dikembangkan baik secara audiovisual maupun dalam tulisan ilmiah dengan tujuan adalah pertama, untuk mengetahui dan melestarikan serta mengembangkan bahwa tari ini memiliki peranan penting dalam menentukan harkat dan martabat suatu daerah yang berbudaya dan beradab. Kedua, dapat memberikan kontribusi yang tinggi 
dalam mengangkat popularitas, kewibawaan, dan keagungan budaya etnik Buleleng baik di tingkat lokal, nasional, maupun internasional. Ketiga, menyadari terhadap eksistensinya yang merupakan bagian dari kebudayaan, maka sangat perlu diteliti secara konprehensif dan holistik, dideskripsikan secara metodologis ke dalam bentuk karya ilmiah. Keempat, meneliti peristiwa-peristiwa budaya khususnya tari Magoak-goakan yang kuat sentuhan budaya lokal selalu dijadikan anak tiri dan masih sangat minim adanya bila dibandingkan dengan bidang ilmu-ilmu lain. Kelima, Salah satu pelestarian budaya daerah dilakukan dengan cara pemanfaatan nilai-nilai budaya melalui pengembangan pariwisata, di antaranya pengembangan pariwisata dilakukan dalam bentuk pertunjukan seni tradisional. Daya tarik wisata budaya, yaitu berupa hasil olah cipta, rasa, dan karsa manusia sebagai makhluk budaya.

(Elina, 2018, hlm. 307). Oleh karena itu, tradisi Magoak-goakan ini sangat berpotensi menjadidaya tarik wisatauntukdikembangkan lebih lanjut yang dapat menumbuhkan perekonomian dan kesejahteraan masyarakat Desa Panji.

Penilitian ini sangat penting dan harus dilakukan yang hasilnya dapat dijadikan sumber informasi tertulis untuk kepentingan studi, pembinaan, dan pengembangan nilai budaya Bali umumnya dan tentang keberadaan tari tradisional Magoak-goakan secara khusus dengan menggunakan judul Eksistensi Tari Tradisional Megoak-Goakan sebagai Representasi Etnisitas Budaya di Kabupaten Buleleng.

\section{METODE}

Jenis data penelitian ini bersifat kualitatif berupa data asal-usul tradisi Magoak-goakan; gaya tari tradisional Magoak-goakan; tari Magoak-goakan dalam perspektif etika, estetika, dan logika. Sumber datanya berupa data primer dan data skunder. Data primer yaitu data diperoleh melalui wawancara dengan tokoh desa adat Panji yang mengetahui dan memahami seni tradisi Magoak-goakan, yaitu I Gusti Nyoman Tiga, serta pengamatan objek secara langsung di Desa Panji. Informan lain adalah Drs. Wayan Sujana (Kabid Kesenian Dinas Kebudyaan Kabupaten Buleleng), dan I Nyoman Arya Suryawan, SST (guru seni tari SMK Negeri 1 Sukasada Buleleng, dan sebagai tim pencipta tari Magoak-goakan). Sedangkan data skunder berupa buku, jurnal, hasil penelitian, dokumen-dokumen terkait dengan fokus penelitian. Pengumpulan datanya melalui studi pustaka (library research) dan studi lapangan (field research) dengan teknik wawancara, observasi, pencatatan dokumen. Teknik analisis data yang digunakan adalah teknik analisis kualitatif. Data kualitatif yang diperoleh dari lapangan tentang eksistensi tari tradisional Magoak-goakan sebagai etnisitas budaya di Kabupaten Buleleng, kemudian diuraikan dalam bentuk deskriptif disertai penafsiran terhadap arti yang terkandung di balik tampak (interpretif). Selanjutnya penarikan kesimpulan atau verifikasi, dilakukan sebagai usaha untuk mencari atau memahami makna mengenai eksistensi tari tradisional Magoak-goakan sebagai etnisitas budaya di Kabupaten Buleleng. 


\section{HASIL DAN PEMBAHASAN}

\section{Asal-usul Tari Tradisional Megoak-Goakan}

Berbicara mengenai tradisi, akan terlintas di benak kita tentang sesuatu yang dilakukan secara berkesinambungan atau terus menerus. Tradisi bisa dikatakan sesuatu yang diwariskan secara turun temurun, oleh karena fungsi dari tradisi tersebut dirasa terus mempunyai manfaat bagi masyarakat tempat tradisi itu lahir dan berkembang, maka dengan segala upaya, masyarakat pemilik tradisi tersebut akan secara bersama-sama berupaya untuk dapat melestarikan kegiatan tradisi tersebut. Dengan kata lain, bentuk sebuah tradisi (termasuk di dalamnya seni), akan menduduki fungsinya yang semula, apabila masyarakatnya menganggap bahwa kesenian mempunyai sesuatu yang dibutuhkan dalam masyarakat.

Kekuatan mempertahankan tradisi akan bergantung pada bagaimana masyarakat pendukung tradisi tersebut dalam ketangguhan prinsip atau ideologi yang kuat mengenai tradisi mereka, misalnya ketangguhan diri untuk tidak terpengaruh dengan perubahan zaman yang memunculkan berbagai persoalan yang kemungkinan bisa menggeser nilai-nilai tradisi yang selama ini sudah mereka tanamkan kepada generasi penerus secara turun temurun. Ketangguhan tradisi dapat saja mengalami masalah, apabila kehadirannya dalam kehidupan masyarakat menjadi jarang. Dengan demikian, penyebaran dan penerusan tradisi pun mengalami hambatan. Ketahanan tradisi itu nampak pula kemampuannya menghadapi kesulitan yang timbul dari keadaan baru, kehidupan masyarakat serta budaya, dan kehidupan beragama. Keadaan baru itu memberikan tantangan dan peluang kepada tradisi. Kekuatan dalam mempertahankan tradisi akan memperkokoh eksistensi dan kelestarian tradisi tersebut di tengah-tengah masyarakat pendukungnya walaupun dalam keadaan pergeseran zaman apapun.

Tari tradisional Magoak-goakan dibentuk oleh unsur-unsur tradisi besar, yaitu tradisi formalis di mana selalu mendapat perhatian, pembinaan, pengayoman, pemeliharaan, dan pengembangan khusus dan serius dari kaum bangsawan yang ada di istana atau puri. Peranan kekuasaan raja sebagai kekuatan kebenaran aksioma, bahkan diyakini sebagai titisan Dewa yang membentuk tari ini menjadi kuat dan sakral (Cerita, 2000, hlm. 29). Berdasarkan bentuk pertunjukannya kuat dengan kaedahkaedah formal kerajaan yang secara koreografis memiliki kompleksitas yang tinggi. Sebagai catatan penting bahwa, pada masa masyarakat feodal di kabupaten Buleleng, yaitu pada masa pemerintahan Raja Panji Sakti dengan pusat pemerintahannya di desa Panji, telah menaruh perhatian dan pengayoman yang baik terhadap perkembangan kesenian termasuk seni tari. Tari tradisional Magoak-goakan merupakan sebuah tarian yang terinspirasi dari permainan tradisi khas kabupaten Buleleng yaitu Magoakgoakan yang berasal dari desa Panji, kecamatan Sukasada, kabupaten Buleleng.

Kelahiran tari ini berkat kecerdasan, imajinasi, dan daya kreativitas leluhur seniman Buleleng dalam mengolah daya cipta, rasa, dan karsanya untuk menciptakan tari Magoakgoakan dengan berakar kuat nilai-nilai tradisi yang ada di Kabupaten Buleleng khususnya di desa Panji. Koreografi tari tradisi, namun tidak lepas dari kreativitas, yaitu mengemukakan sesuatu hal yang selalu baru, segar, dan 
terus mengalir dalam perekonstruksiannya (Rustiyanti dkk, 2021, hlm. 189). Permainan Magoak-goakan diperkirakan sudah ada pada masa pemerintahan Ki Gust Ngurah Panji Sakti di Buleleng, raja yang berkuasa pada masanya yaitu pada tahun 1660 M sampai dengan 1697 M. Ki Barak Panji Sakti adalah seorang raja yang terkenal di samping sifatnya yang gagah berani dan sakti, begitu juga arif dan bijaksana serta berbudi luhur. Didampingi oleh para mahapatih yang hebat dan kuat serta ketangguhan dan kesetiaan prajuritnya yang senantiasa selalu siap siaga menjaga keamanan dan kenyamanan rakyat dan seluruh wilayah kekuasaannya yang disebut Teruna Goak. Pasukan Teruna Goak dibentuk secara khusus ditempa dengan ilmu bela diri yang tangguh dan digdaya yang dipimpin oleh mahapatih sakti penuh dedekasi dan bertanggung jawab bernama I Gusti Made Bahatan.

Penyerangan Taruna Goak ke Blambangan, dengan Laskar Den Bukit "Taruna Goak" telah dipersiapkan dengan segala kemampuan oleh I Gusti Anglurah Panji, karena prajurit Blambangan dengan pasukan berpengalaman perang yang terkenal kebal senjata dengan ilmu tenung. Persenjataan Taruna Goak berupa keris, tombak dan panah juga dikembangkan senjata sumpit dengan panah beracun. Laskar dibagi empat bagian, termasuk armada kapal laut, pasukan panah, sumpit, tombak termasuk pasukan senjata api (bedil) dan logistik. Setelah ditentukan hari yang baik oleh Sang Bhagawanta mulailah pasukan bertolak ke Blambangan dipimpin oleh I Gusti Ngurah Panji berbekal senjata keris pusaka Ki Semang dengan tulup Ki Pangkajatattwa. Selain itu ada dua senjata bertuah asli buatan Banjar,
Ki Baru Ketug dibawa oleh I Gusti Tamlang dan Ki Baru Sakoti dibawa oleh I Gusti Batan. Armada kapal berlayar melalui Segara Rupek menuju pantai Tirta Arum. Pasukan Bali sangat ahli mempergunakan senjata sumpit sehingga banyak jatuh korban dari pihak laskar Macan Putih tidak mampu menandingi pasukan Bali, dengan demikian Kerajaan Blambangan dapat dikuasai oleh I Gusti Ngurah Panji. Ribuan prajurit Blambangan menyerahkan diri kepada Patih I Gusti Tamblang dan bersumpah setia kepada I Gusti Anglurah Panji Raja Den Bukit. Setelah beberapa lama berada di Blambangan, beliau mengangkat putranya tertua I Gusti Ngurah Wayan sebagai Raja Blambangan dengan pasukan prajurit 600 orang (Simpen, 2003, hlm.34).

Permainan Magoak-goakan muncul terinspirasi dari burung gagak (goak) saat melintas dihadapan Raja Panji Sakti, lalu burung gagak tersebut mencuri perhatian Sang Raja. Ketika itulah Sang Raja melihat burung gagak sedang mengincar mangsanya dengan menggunakan taktik dan strategi jitu sehingga burung gagak dengan secepat kilat dapat menangkap mangsanya. Kehebatan burung gagak tersebut dijadikan fenomena yang sangat unik dan menarik yang oleh Sang Raja Ki Barak Panji Sakti lalu dijadikan inspirasi sebagai siasat, taktik, dan strategi berperang ketika menggempur kerajaan Blambangan di Jawa. Sebelum keberangkatannya untuk bertempur ke Blambangan, Sang Raja Ki Barak Panji Sakti menuangkan taktik dan strategi tersebut ke dalam bentuk permainan yang diberinya nama Magoak-goakan.Permainan ini selalu ditampilkan secara periodik setiap tahun oleh masyarakat desa Panji yaitu tepatnya sehari 
setelah hari raya Nyepi (tahun baru saka di Bali).

Bentuk permainannya adalah diawali dengan Sang Raja Ki Barak Panji Sakti memerintahkan prajuritnya untuk bermain dengan dilandasi peraturan dan perjanjian yang sangat ketat. Semua prajurit berjanji kehadapan Sang Raja bahwa apabila Sang Raja dapat memenangkan permainan tersebut dengan cara dapat menangkap barisan yang paling belakang, maka segala perintah Sang Raja harus dipenuhi dan dijalankan dengan sungguh-sungguh. Permainan berlangsung dengan penuh semangat. Semua prajurit berbaris ke belakang dengan masing-masing memegang pinggang teman yang di depannya, Sang Raja bergerak lincah dan tangkas sehingga dengan mudah bisa menangkap barisan yang paling belakang. Dengan berhasilnya memenangkan permainan tersebut, kemudian Sang Raja Ki Barak Panji Sakti memerintahkan seluruh pasukannya untuk berangkat ke medan laga yaitu ke Blambangan dengan menggunakan perahu yang mana ketika itu Blambangan dikuasai oleh Raja Jagaraga. Spirit dan semangat permaianan Magoakgoakan dimanfaatkan untuk membangkitkan jiwa heroik dan patriotisme dari seluruh pasukannya untuk mengalahkan Blambangan. Melalui pertempuran yang sengit dan seru Raja Jagaraga beserta seluruh pasukannya dapat dikalahkan, sehingga Blambangan menjadi kekuasaan kerajaan Buleleng. Bentuk dan spirit permainan Magoak-goakan itulah ditransformasi ke dalam sebuah karya tari yang bertemakan kepahlawanan oleh para leluhur seniman Buleleng yang sampai sekarang digolongkan dalam tari tradisional khas Buleleng yang

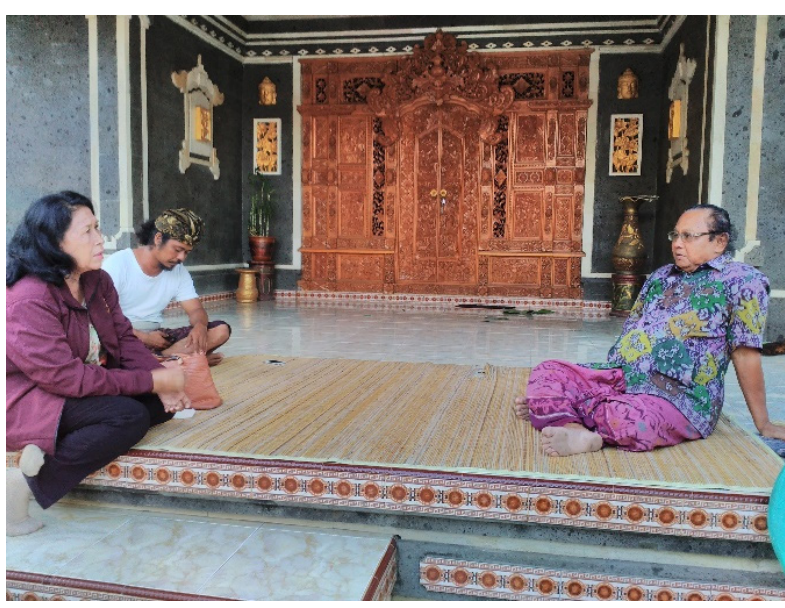

Gambar 1. Wawancara Penulis dengan Bapak I Gusti Nyoman Tiga di Desa Panji Kabupaten Buleleng (Sumber: Sustiawati, 10 Juli 2016)

sekaligus sebagai kesenian etnik yang satu-satu yang hanya ada di kabupaten Buleleng. Hasil wawancara dengan I Gusti Nyoman Tiga bahwa Magoak-goakan sebagai seni tradisi mengandung nilai keindahan yaitu dapat membangkitkan semangat dan rasa gembira bagi pemain dan para penontonnya. Aksi kejar-kejaran yang dilakukan goak ingin menangkap ekor dan ekor dapat tertangkap oleh goak membuat penonton bersorak ria dan merasa terhibur.

\section{Gaya Tari Tradisional Magoak-goakan} sebagai Representasi Etnisitas Budaya

Pulau Bali sebagai sebuah propinsi terdiri atas 8 (delapan) kabupaten dan satu kota madya, yaitu: Kabupaten Buleleng, Karangasem, Bangli, Klungkung, Gianyar, Kota Denpasar, Tabanan, dan Jembrana. Pulau Bali secara umum memiliki karakteristik tari tradisional sebagai gaya dan represesntasi dari budaya etnis Bali, yaitu: gaya Bali Utara (Buleleng) dan Gaya Bali Selatan yaitu seluruh kabupaten/kota yang berada di luar kabupaten Buleleng. Terdapat berbagai macam gaya tari tradisional yang masing-masing memiliki karakteristik dan ciri-ciri tersendiri sebagai 
identitas dari suatu daerah. Berbicara masalah etnisitas tidak bisa dipungkiri menyangkut masalah komunalitas, budaya, ideologi, kefanatikan bahkan konflik. Untuk mengawali pembicaraan di dalam memberikan gambaran umum tentang etnisitas akan dimulai dari pendapatnya Dr. Agus Salim, MS dalam bukunya yang berjudul Stratifikasi Etnik Kajian Mikro Sosiologi Interaksi Etnis Jawa dan Cina adalah sebagai berikut:

Masing-masing etnis memiliki prilaku budayanya sendiri yang hidup dan berkembang dengan wajar dan alamiah dalam bentuk-bentuknya yang spesifik. Masing-masing etnis saling beriteraksi, memiliki mobilitas yang kuat karena kebutuhan ekonomi dalam jalur perdagangan antar pulau dan juga jalur penyebaran tenaga kerja. Masing-masing etnis kemudian terlibat dalam pola interaksi yang intensif yang menghasilkan tata pergaulan masyarakat yang beragam dikenal dengan "hetero cultural society" (Agus Salim, 2006:3).

Berbicara masalah etnisitas dalam tari tradisional tidak bisa terlepas dari pembicaraan tentang gaya atau stail. Karena gaya secara implisit dan eksplisit sangat menentukan nilai-nilai etnisitas dari suatu daerah. Ungkapan yang menarik tentang gaya oleh Edi Sedyawati (1994: 21 dalam Sukerta, 2009, hlm. 24-25) menyebutkan bahwa:

Gaya seni adalah "gugusan dua ciri atau lebih yang merupakan fungsi zaman atau wilayah," pada dasarnya tidak berbeda dengan beberapa pendapat lain yang pernah diberikan orang khusus berhubungan dengan gaya seni. Balasubrahmanyam mengutip Rowland dalam membahas kesenian Hindu adalah segala kekhasan penampakan dan struktur dalam suatu karya arsitektur, seni arca atau seni lukis, yang dengan alasannya dan cara penciptaannya, membuatnya khas.

Mengacu pendapat di atas, bahwa secara konsep gaya tari tradisional Magoakgoakan sebagai budaya etnik dibentuk oleh norma-norma, pakem-pakem, nilai-nilai, keyakinan dan simbul-simbul serta praktik budaya bersama dalam wilayah kabupaten Buleleng sebagai bagian dari wilayah pulau Bali. Dengan perkataan lain pembentukan tari ini sebagai salah satu kelompok dalam katagori gaya tari tradisional Bali telah diikat ketat dengan norma-norma atau pakempakem secara formalis. Ia telah diwariskan dari generasi ke generasi, dari zaman ke zaman sehingga mengkristal sampai pada puncaknya, sehingga menjadi eksis sampai sekarang sebagai bagian seni pertunjukan Bali. Sebagai identitas budaya yang menceritakan Raja Panji Sakti melakukan permainan Magoak-goakan bersama seluruh pasukan Taruna Goak dalam membangkitkan rasa heroik dan patrotisme untuk menaklukkan Kerajaan Blambangan di Jawa Timur, memiliki gaya atau style dengan ciri-ciri gerak sangat dinamis, semangat dan rasa gembira bagi pemain dan para penontonnya. Aksi kejar-kejaran yang dilakukan goak ingin menangkap ekor dan ekor dapat tertangkap oleh goak membuat penonton bersorak ria dan merasa terhibur. Perbendaharaan geraknya terdiri dari ngepakan sayap, lompat-lompat, terbang, menangkap mangsanya. Gerakan ini terinspirasi dari ketangkasan dan kehebatan burung goak dalam menangkap mangsanya. 


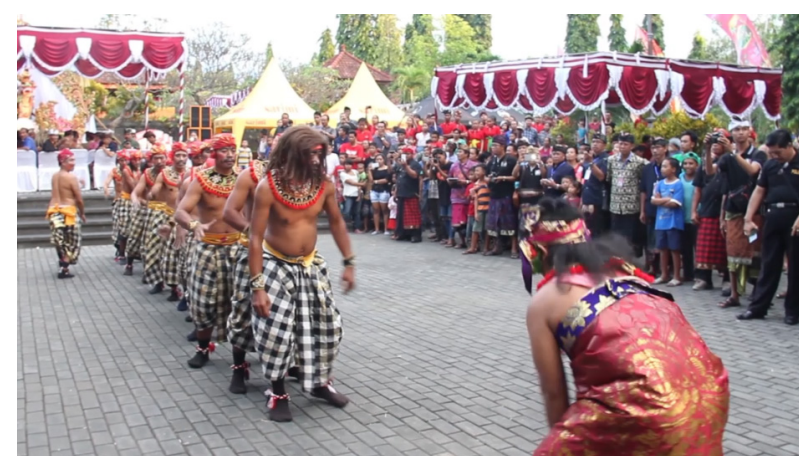

Gambar 2. Seni Tradisi Magoak-goakan (Sumber: Sustiawati, 20 Juli 2016)

Tari Megoak-Goakan Dalam Perspektif Etika, Estetika, dan Logika

\section{Etika}

Etika secara teoretisadalah pengkajiansoal moralitas atau terhadap nilai tindakan moral. Istilah ini juga dipakai untuk menunjukkan sistem atau kode yang dianut. Secara teologis etika adalah nilai-nilai kebijaksanaan dan kebaikan yang harus dilakukan dan ditegakkan oleh setiap umat manusia. Nilai yang berisifat layak atau tidak layak dari kehidupan munusia dapat diukur dari ketaatan dan ketulusan di dalam menjalankan ajaran-ajaran agama. Sebagai bentuk ajaran bersifat normatif etika merupakan prinsip-prinsip yang menjadi dasar bentuk moral dari tindakan manusia yaitu mengatur tingkah laku manusia dalam berhubungan dengan sesamanya, dengan lingkungan, dan dengan Tuhan Yang Maha Esa.

Nilai-nilai etika dalam tari tradisional Magoak-goakan menjadi esensial di dalam membangun pertunjukan yang bermakna. Tari ini telah diyakini menjadi media yang paling ampuh untuk mentransformasi, mengaktualisasikan, dan menyosialisasikan nilai-nilai moral kehidupan masyarakat. Hal itu disebabkan oleh karena tari merupakan ungkapan ekspresi dan komunikasi yang universal yang dapat dinikmati dan dihayati oleh siapa saja, kapanpun, dan di manapun. Secara teoritis tari dapat sebagai cermin kehidupan bagaimana tarian kehidupan manusia di saat ini atau bagaimana tingkah laku yang harus dilakukan berdasarkan norma agama yang dianut (Artadi, 2011, hlm. 183). Beranalogi dari pendapat tersebut bahwa, tari tradisional Magoak-goakan mengandung makna kemanusiaan dan dikemas secara artistik dan filosofis berdasarkan kaedah-kaedah agama Hindu yang meliputi:(1)nilai religius (kebaikan) yang merupakan keyakinan orang Bali terhadap kekuatan ilahi yaitu Tuhan. Melalui simbolsimbol dan sarana-sarana suci yang bersumber dari agama Hindu yang terdapat di dalam tari ini diyakini mampu mengendalikan diri dari perbuatan-perbuatan atau tingkah laku yang tidak baik. Semua aktivitas tersebut dilandasi oleh ketulusan, kejujuran, atau pengorbanan suci secara tulus ikhlas yang bertujuan untuk menjaga keharmonisan, keselarasan, dan cinta kasih; (2) nilai kebaikan selalu disandingkan nilai kebatilan, yang merupakan nilai pembanding sekaligus pendamping terhadap nilai kebaikan. Kehidupan orang Bali masih memegang teguh filosofi yang disebut dengan rwabineda yaitu terdapat dua kekuatan yang tidak bisa dipisahkan di antara keduanya, yaitu baik/buruk, kuat/lemah, siang/malam, tinggi/rendah, surga/neraka, dan lain-lain. Hal itu dijadikan kriteria di dalam kehidupan sehari-hari yang dilandasi dengan hukum alam yang disebut dengan karma pala. apabila kita berbuat jelek diyakini akan mendapatkan karma yang jelek dan mendapat tempat di neraka. Begitu pula sebaliknya apabila kita betingkah laku yang baik akan mendapatkan 
kebahagiaan sejati yang bertempat di surga menyatu dengan Tuhan. Kedua nilai tersebut di dalam pertunjukkan tari Magoak-goakan ditransformasi dan divisualkan melalui gerakgerak ekspresif dan dramatik yang terdapat di masing-masing adegan, yaitu: adegan pertama (pepeson) menggambarkan perbuatan yang baik (keharmonisan, kebersamaan, dan kedamaian) dari para prajurit yang tangguh.

Adegan kedua (pengawak) menggambarkan tingkah laku yang baik dalam suasana magis religius Raja Ki Barak Panji Sakti sedang sembahyang memohon kehadapan Tuhan Yang Maha Esa agar dianugrahkan keselamatan dan kesuksesan dalam perjuangan untuk mempertahankan tanah leluhurnya (Buleleng) dari serangan Kerajaan Blambangan. Sekaligus dalam adegan ini pula Sang Raja mempersiapkan seluruh prajuritnya untuk melakukan permainan Magoak-goakan. Di saat peralihan dari pengawak ke pengecet sangat kental dan kuat ditonjolkan adalah nilainilai etika, yang digambarkan dalam motifmotif gerak dan suasana kesucian, seperti melakukan persembahayangan bersama di pura Pajenengan yang dibangun oleh Raja Ki Barak Panji Sakti. Persembahyangan dilakukan untuk memohon keselamatan dan kelancaran saat pelaksanaan Magoak-goakan. Berdasarkan kegiatan yang dilakukan, dapat dipetik nilai religius dari pelaksanaan persembahyangan tersebut, yaitu sebelum melakukan aktivitas sebaiknya kita selalu mengingat Tuhan Yang Maha Esa dengan melaksanakan doa bersama. Selain itu, ada proses pendewasaan rohani dan jasmani bagi pelakunya, dapat membantu manusia untuk menjalin rasa persaudaraan dan kesejahteraan. Setelah persembahayangan, peserta mengelilingi desa diiringi gamelan Bleganjur, menuju tempat tradisi Magoakgoakan tersebut diadakan, yaitu Lapangan $\mathrm{Ki}$ Barak Panji. Adegan pengecet menggambarkan etika permainan Magoak-goakan yang disiplin taat dengan perjanjian dan aturan permaianan. Bagian Akhir adalah bagian penutup (pekaed) menggambarkan seluruh pasukan di bawah pimpinan Raja Ki Barak Panji Sakti sedang berangkat ke Blambangan dengan menggunakan perahu kapal sebagai kesatria yang gagah berani.

\section{Estetika}

Berbicara tentang estetik berarti membahas tentang keindahan. Estetika dipandang sebagai suatu filsafat ditempatkan pada titik dikotomis antara realitas dan abstrak, juga antara keindahan dan makna (Rustiyanti, 2011, hlm. 293). Begitu pula dengan tari tradisional Magoak-goakan sebagai karya seniman merupakan ungkapan ekspresi senimannya yang paling dalam untuk mendapatkan nilai estetik yang bermakna bagi penonton dan masyarakat. Estetika merupakan unsur terpenting di dalam tari ini untuk menunjukkan nilai-nilai keistimewaan dan sekaligus sebagai karakteristik dan identitasnya. Estetika diwujudkan melalui simbol-simbol gerak, ritme, nilai, dan pesan dikemas sedemikian rupa secara artistik dan filosofis ke dalam sebuah pertunjukkannya yang khas. Berdasarkan bentuk pertunjukkannya dapat diamati sebagian besar penggambaran estetiknya bersifat imajinatif yang mengarah kepada unsur-unsur rialitas dan metakinesis. Permainan Magoak-goakan ini bertemakan kepahlawanan yang awalnya dimainkan 
oleh pemain putra diatur dengan pola lantai membentuk garis lurus berjejer, namun perkembangan selanjutnya sebagai sebuah pertunjukan Magoak-goakan juga dimainkan oleh pemain putri. Pemain di depan (pemain goak) harus menangkap ekor (pemain yang ada di belakang, yang disebut Kacang), jika ekornya sudah tertangkap maka permainan tersebut dianggap selesai. Magoak-goakan sebagai seni tradisi mengandung nilai keindahan yaitu dapat membangkitkan semangat dan rasa gembira bagi pemain dan para penontonnya. Aksi kejar-kejaran yang dilakukan goak ingin menangkap ekor dan ekor dapat tertangkap oleh goak membuat penonton bersorak ria dan merasa terhibur, serta dapat membantu pelakunya untuk menjalin rasa persaudaraan dan kesejahteraan.

Seperti diuraikan di dalam bagian terdahulu bahwa tari ini secara konseptual diciptakan bertitik tolak kepada budaya lokal Buleleng dengan sendirinya nilai-nilai estetika yang mempengaruhi dengan kuat dan integral adalah bercirikan ekspresi estetik yang berlandaskan kehidupan masyarakat Buleleng yang dilandasi agama Hindu. Apabila disimak secara lebih mendalam mengandung ciri-ciri utama sebagai berikut:

\section{Bersifat Kontemplatif-Transendental}

Pengungkapan rasa keindahan yang mendalam di dalam Magoak-goakan secara implisit dan eksplisit mengaitkanya dengan perenungan (kontemplasi) baik terhadap yang Maha Kuasa, para leluhur, maupun alam semesta serta pengejawantahan dari dunia mistis.Apapunyang diungkapkanmengandung makna untuk mengagungkan sesuatu atau mengungkap sesuatu yang banyak dipengaruhi oleh berbagai hal, seperti: pengaruh dokma agama, adat kebiasaan, daerah, teknik, bahan dan norma. Unsur-unsur persembahan, magis religius, dan keseimbangan makrokosmos, mikrokosmos, dan metakosmos sebagi ciri-ciri berkesenian di Bali menjadi landasan sangat kuat di dalam pengungkapan rasa estetiknya. Tradisi Magoak-goakan erat kaitannya dengan ajaran agama Hindu dan prilaku sosial religius masyarakat Bali yang di jiwai oleh ajaran agama Hindu. Hal ini disebabkan napas dari kebudayaan Bali adalah ajaran Agama Hindu. Yang inti ajarannya Sanatana Dharma, yaitu satyam (kebenaran), siwam (kesucian), dan sundaram (keindahan). Ajaran ini dapat diartikan bahwa dengan menegakan kebenaran, kemuliaan dan kesucian yang berlandaskan dari keharmonisan keindahan dalam kehidupan masyarakatnya dan diaplikasikan ke dalam keseimbangan yang diwujudkan dengan menunjukkan rasa bakti terhadap Tuhan/Ida Sang HyangWidhi Wasa, lingkungan hidup dan mayarakat Bali. Ajaran Tri Hita Karana adalah tiga hubungan yang harmonis yang menyebabkan kebahagiaan bagi umat manusia. Tiga hubungan yang harmonis antar manusia dengan penciptanya (prahyangan), manusia dengan alam (palemahan), dan manusia dengan sesamanya (pawongan) (Windia, 2006, hlm. 26). Dalam pelaksanaan tradisi Magoak-goakan mendekatkan diri dengan Dewa-Dewi dan para leluhur, diawali dengan persembahyangan di pura Pajenengan Panji untuk memohon keselamatan agar manusia dapat menjalin rasa persaudaraan dan selalu menjaga lingkungannya (Sustiawati, 2017, hlm. 203). 


\section{Bersifat simbolistik}

Secara semiotik tari tradisional Magoakgoakan merupakan rangkaian simbol-simbol yang distruktur dan diinternalisasikan sebagai bagian dari kebudayaan yang mengandung makna kemanusiaan. Simbol-simbol tersebut bukan sembarang tanda dan penanda namun sesuatu yang telah mengalami proses internalisasi dan sakralisasi berdasarkan keyakinan yang bersumber dari agama Hindu. Dengan kata lain tari ini pada hakikatnya merupakan rangkuman dari tindakan-tindakan simbolis yang terpadu dengan unsur-unsur artistik dan filosofis menjadi satu kesatuan yang utuh yang mencerminkan sifat-sifat kehidupan sosiokultural masyarakat Bali khususnya Buleleng. Permainan tradisional Magoak-goakan adalah salah satu tradisi masyarakat Panji Kabuputen Buleleng yang masih dipertahankan dan dimainkan pada saat ngembak geni, yang merupakan rangkaian Hari Raya Nyepi. Oleh masyarakat Buleleng (Bali Utara) permainan ini benar-benar mempunyai nilai heroik karena berkat taktik inilah Raja Panji Sakti dapat mengobarkan semangat juang yang spontan daripada rakyatnya. Permainan ini tetap disukai oleh masyarakat Buleleng bahkan meluas ke seluruh Bali, karena di samping bernilai heroik juga sebagai hiburan, olah raga, dan ada pesan atau nilai-nilai yang mampu mempengaruhi perilaku seseorang.

\section{Bersifat filosofis}

Berdasarkan makna tema, tari tradisional Magoak-goakan merupakan penjabaran berbagai ungkapan yang didasari atas kemuliaan dan keluhuran budi. Ungkapan-ungkapan filosofis tersebut dapat dilihat pada nilai- nilai sebagai berikut (1) nilai kebenaran dan kejujuran merupakan prinsip dasar hidup dan kehidupan manusia Hindu (Suhardana, 2006, hlm. 68). Unsur kebenaran dan kejujuran dapat dilihat dari tokoh Ki Gusti Ngurah Panji Sakti saat berjanji akan memberikan hadiah apapun yang diminta, jika prajurit goak tersebut berhasil menangkap ekor (prajurit yang berada paling belakang). Kejujuran dan kebenaran dari sikap Ki Gusti Ngurah Panji Sakti tersebut dapat mencerminkan tindakan yang baik menjadikan dirinya sebagai orang yang selalu dapat dipercaya dalam perkataan, tindakan, dan pekerjaan, baik terhadap diri sendiri maupun pihak lain. Sikap kejujuran dan kebenaran tersebut sangat penting dan harus diterapkan pada lingkungan sekitar; (2) Nilai ketekunan dan kerja keras, dijelaskan oleh Deni Damayanti (2014) adalah perilaku yang menunjukkan upaya sungguh-sungguh dalam mengatasi berbagai hambatan guna menyelesaikan tugas, baik tugas belajar maupun tugas pekerjaan dengan sebaik-baiknya. Ketekunan dan kerja keras dalam Magoak-goakan dapat dilihat dari pemain goak berlari-lari dan mengincar ekor (penari paling belakang). Goak disini dengan usaha dan ketekunannya mengincar ekor tersebut hingga tertangkap, dan sangat teliti dalam melihat gerak-gerik ekor yang selalu menghindar dari kejarannya, namun goak tetap bangkit dan semangat mengejar ekor tersebut hingga pada akhirnya dapat tertangkap. Pemain yang lain juga kerja keras menghalangi goak yang ingin mengincar ekor. Nilai ketekunan dan kerja keras yang terkandung dalam Magoak-goakan ini dapat diterapkan kepada masyarakat untuk selalu berusaha dengan kerja keras dan tekun agar mendapatkan hasil 
yang ingin dicapai; (3) Nilai Keluhuran Budi, menurut Suhardana (2006), keluhuran budi hanya bisa tercipta dengan perbuatan yang baik dan mulia. Keluhuran budi akan menghasilkan sesuatu yang bermanfaat dikemudian hari. Perbuatan yang baik dan mulia dalam Magoakgoakan dapat dilihat dari sikap kesetiakawanan sosial, solidaritas para pemain dengan gerakangerakan lincah yang kadang kala berlari, menari, jongkok, merayap berputar-putar, berbalik, atau melompat ke sana ke mari untuk menjaga dan mempertahankan barisan agar terhindar dari incaran pemain goak, walaupun pada akhirnya ekor tersebut juga tertangkap. Kearifan lokal Magoak-goakan ini dapat memberi nilai-nilai penguatan dan memperteguh perilaku kesetiakawanan sosial yang sekarang ini semakin luntur, perlu dibangkitkan kembali sebagai pondasi memperkokoh kebhinekaan dan memperkuat restorasi sosial; (4) Nilai kepahlawanan. Pahlawan lekat dengan tentara perang yang berjuang membela negara, mempertahankan kemerdekaan, menjaga keamanan, rela berkorban, cinta tanah air, senasib sepenanggungan memiliki nilai filsafat yang luar biasa yang membuat tidak egois, tidak sombong dan selalu mengedepankan kepentingan umum di atas kepentingan pribadi dan golongan. Menanamkan nilainilai kepahlawan sangat tepat diberikan sejak usia dini, agar memahami arti penting dari mengingat jasa-jasa para pahlawan dan mengaplikasikan nilai-nilai luhur yang dilakukan oleh para pahlawan.

\section{Logika}

Logika merupakan cabang filsafat yang membicarakan tentang watak, dan problem-problem pemikiran yang jelas dan tepat serta argumen-argumennya. Sebagai ilmu pengetahuan yang berfungsi untuk menjelaskan suatu fakta dan permasalahan sesuai dengan akal sehat, wajar, masuk akal, dan diakui kebenarannya. Logika adalah alam pikiran sadar, intelektualitas yang dapat membahasakan, menjelaskan, merumuskan, menyimpulkan dan mengilmiahkan semua aspek etika dan estetika yang ada di dalam tarian. Logika yang bersosok ilmu pengetahuan berperan penting di dalam membahasakan, mentransformasi, mengaktualisasi, dan menyosialisasikan nilai-nilai dan pesan-pesan yang ada di dalam tari ini. Logika sebagai ilmu pengetahuan juga dapat mengkomunikasikan tentang eksistensi tari. Jadi logika dapat membangun dan memperkuat kebenaran dan keyakinan dari tari yang secara intelektual menjadi pertunjukan yang berkualitas, berbobot dan bisa dimengerti, dipahami, dan dipercaya oleh penonton dan masyarakat.

Logika pada tradisi Magoak-goakan tercermin pada nilai-nilai dan pesan-pesan sebagai berikut, yaitu pada nilai budi pekerti, hasrat bersemangat membela kebenaran, mengentaskan keangkaramurkaan yang diberikan oleh Raja Panji Sakti kepada Rakyat Buleleng. Nilai dan pesan yang disampaikan adalah pesan perjuangan atau kepahlaman yang dapat membentuk karakter dan jati diri, mempertebal rasa percaya diri, memperkokoh jiwa persatuan dan kesatuan dalam masyarakat, meningkatkan rasa solidaritas, memperkuat kepribadian dan kebanggaan wilayahnya, menjunjung tinggi nilai-nilai dan martabat serta status sosial masyarakat, memperhalus budi dan sikap dari masyarakat. Dengan 
demikian melalui tata nilai etika dan logika, seseorang mampu memelihara kepribadian dan jati dirinya sebagai seorang yang bermoral. Kehadiran permainan tradisional Magoak-goakan berfungsi mengenalkan dan mengakrabkan peristiwa-peristiwa yang pernah dialami dan dilakukan para leluhur pada masa lampau. Hal ini pada hakikatnya juga memberikan hikmah dalam menumbuhkan rasa hormat serta rasa memiliki di hati para penerusnya, serta dapat menumbuhkan karakter bangsa pada anakanak, sehingga anak-anak menghormati jasajasa para leluhur dan pahlawannya.

\section{Iringan Tradisi Magoak-goakan}

Keunikan permainan ini juga dimainkan dengan iringan musik dari gamelan yang bernama Balaganjur Teruna Goak. Hal yang menarik dari musik iringan ini adalah melodi utama yang dimainkan oleh instrumen reyong (satu-satunya instrumen yang memainkan melodi pada gamelan Balaganjur). Surya (2019, hlm. 13) menyebutkan bahwa instrumen reyong ini memainkan melodi yang sederhana dan sangat mudah diingat dan diiringi dengan suara cengceng kopyak yang dimainkan secara bersahut sahutan dengan teknik kakilitan dan cecandatan. Pola ritmenya bervariasi dari pukulan basic atau negteg pukulan "telu” (tiga) dan "enam" (enam) di mana masing-masing terdiri dari pukulan polos (sejalan dengan mat/ ketukan) dan sangsih (disela-sela mat). Pola ini dimainkan dengan ekspresi bersemangat yang menghasilkan suasana riuh dan riang yang menambah keseruan dalam permainan Magoak-goakan ini. Instrumen lain berupa 2 (dua) buah kendang cedungan (lanang wadon), 1 (satu) buah kajar, 1 (satu) buah kempli, 2 (dua) buah gong besar, 1 (satu) buah kempur dan 1 (satu) buah pemade. Barungan ini ada kalanya dimainkan dengan tawa-tawa. Tabuh- tabuh yang dimainkan dalam Balaganjur terdiri dari gilak yang dimainkan dalam tempo cepat atau sedang dan pelan.

\section{SIMPULAN}

Tari tradisional Magoak-goakan menggambarkan jiwa heroik dan patriotisme pasukan Raja Ki Barak Panji Sakti dari kerajaan Buleleng yang disebut dengan Teruna Goak yang senantiasa selalu siap siaga menjaga keamanan dan kenyamanan wilayahnya. Kelahiran tari ini terinspirasi dari permainan tradisional Magoak-goakan menggambarkan jiwa heroik dan patriotisme pasukan Raja Ki Barak Panji Sakti dari kerajaan yang dicetuskan oleh Raja Ki Barak Panji Sakti pada tahun 1660 M di Desa Panji, Kecamatan Sukasada. Tari ini merupakan warisan leluhur yang bersifat luhur dan telah menjadi khasanah budaya Bali yang adiluhung sehingga dimuliakan oleh masyarakat Buleleng khususnya desa Panji yang dipentaskan setiap tahun sekali tepatnya sehari setelah hari raya Nyepi. Dalam perkembangan selanjutnya juga dipentaskan dalam rangka hari-hari penting baik dalam acara formal maupun informal.

Berdasarkan bentuk pertunjukannya tari tradisional Magoak-goakan menggambarkan jiwa heroik dan patriotisme pasukan Raja Ki Barak Panji Sakti dari kerajaan bertemakan kepahlawanan yang ditarikan oleh lima orang penari berkarakter putra keras, dan diiringi dengan gamelan gong kebyar khas Buleleng. Secara koreografis tari ini berbentuk tari masal 
yang di dalamnya tercermin kehebatan dan keagungan nilai-nilai budaya lokal terjalin secara integral, harmonis, ritmis, dinamis, dan indah serta penuh makna. Fungsi dan makna yang tersirat di dalamnya tidak hanya sebagai tontonan belaka akan tetapi lebih dalam dariitu sarat dengan nilai-nilai tuntunan dan tatanan. Berangkat dari gaya dan karakteristiknya yang unik dan menarik serta kemuliaan fungsi dan maknanya, tari tradidional Magoak-goakan menggambarkan jiwa heroik dan patriotisme pasukan Raja Ki Barak Panji Sakti dari kerajaan telah menjadi bagian dari etnisitas budaya yang sampai sekarang tetap dilestarikan dan dikembangkan sesuai dengan entitas, kualitas, dan norma-norma serta kaidah-kaidah yang dimiliki.

\section{UCAPAN TERIMA KASIH}

Kami mengucapkan terima kasih kepada pemerintah Republik Indonesia cq Direktur Riset dan Pengabdian Masyarakat Ditjen Penguatan Riset dan Pengembangan Kemenristekdikti telah memfasilitasi proses penelitian seni tradisi Magoak-goakan tahun 2016-2017.

Pada kesempatan ini penulis menyampaikan ucapan terima kasih kepada Bapak Rektor Institut Seni Indonesia Denpasar beserta jajarannya, Pengelola Jurnal Panggung Institut Seni Budaya Indonesia (ISBI) Bandung, para nara sumber dan semua pihak yang membantu secara langsung maupun tidak langsung dalam penyelesaian dan sampai terpublikasi tulisan ini. Semoga tulisan ini bermanfaat.

\section{DAFTAR PUSTAKA}

Artadi, I Ketut (2011). Kebudayaan Spiritualitas Nilai Makna dan Martabat Kebudayaan Demensi Tubuh, Akal, Roh dan Jiwa. Denpasar: Pustaka Bali Post

Atmaja, Nengah Bawa. (2010). Ajeg Bali Gerakan, Identitas Kultural, dan Globalisasi. Yogyakarta: LkiS.

Cerita, I Nyoman, (2000). Tari Kontemporer Dalam Pesta Kesenian Bali Antara Eksistensi, Hegemoni, dan Marginalisasi. Denpasar: Japa

Damayanti, Deni. (2014). Panduan Implementasi Pendidikan Karakter Di Sekolah. Araska: Yogyakarta.

Elina, Misda. dkk. 2018. Pengemasan Seni Pertunjukan Tradisional Sebagai Daya Tarik Wisata di Istana Basa Pagaruyung. Panggung Vol. 28 No 23, September 2018, 307.

Lijan Poltak Sinambela, dkk. (2014). Reformasi Pelayanan Publik Teori, Kebijakan, dan Implementasi. Jakarta: Bumi Aksara.

Rustiyanti, Sri. (2011). Konsep Estetik Tari Minang dari Tradisional ke Kontemporer. Panggung. Vol. 21. N0 3 Juli-September 2011, 293-305

Rustiyanti, Sri, dkk. (2021). Ekranisasi AR PASUA PA: dari Seni Pertunjukan ke Seni Digital sebagai Upaya Pemajuan Kebudayaan. Mudra. Vol. 36. No 2. Mei 2021, 186-196.

Salim, Agus. (2006). Stratifikasi Etnik Kajian Nikro Sosiologi Interaksi Etnis Jawa dan Cina. Jogyakarta: Tiara Wacana.

Simpen, I W. (2003). Riwayat Kerajaan Buleleng (Buku Sejarah Ki Barak Panji Sakti). Surabaya: SIC.

Sugiyono. (2013). Metode Penelitian Pendidikan Pendekatan Kuantitatif, Kualitatif, dan $R$ $\mathcal{E} D$. Bandung: Alfabeta.

Suhardana, K.M. (2006). Pengantar Etika dan Moralitas Hindu: Bahan Kajian Untuk Memperbaiki Tingkah Laku. Surabaya: Paramita.

Sukerta, I Pande. (2009). Gong Kebyar Buleleng: Perubahan dan Keberlanjutan Tradisi Gong Kebyar. Surakarta: Program Pascasarjana bekerjasama dengan ISI Press Surakarta.

Sumardjo, Jakob. (2000). Filsafat Seni. Bandung: 
506

ITB.

Surya, Ade Firdaus, dkk. (2019). Transformasi Musik Balaganjur Teruna Goak ke dalam Musik Jazz. Panggung. Vol. 29.No.3, Juli-September 2019, 205-217

Sustiawati, dkk. (2017). Pengembangan Desain Pembelajaran Seni Tari Di Sekolah Dasar Berbasis Localgenius Knowledge Berpendekatan Integrated Learning. Mudra Jurnal Seni Budaya Vol. 32 No. 2, Mei 2017/12 , 197-208.

Windia, Nyoman, (2006). Konsep Tri Hita Karana Dalam Tradisi Bali. Surabaya: Paramita. 